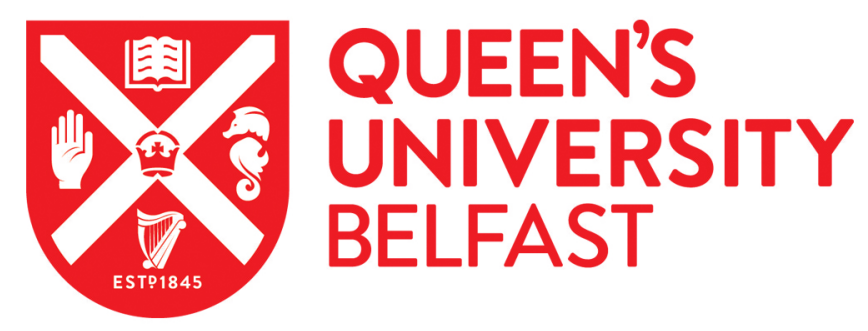

\title{
Evolving national park models: The emergence of an economic imperative and its effect on the contested nature of the 'national' park concept in Northern Ireland.
}

Bell, J., \& Stockdale, A. (2015). Evolving national park models: The emergence of an economic imperative and its effect on the contested nature of the 'national' park concept in Northern Ireland. Land Use Policy, 49, 213226. https://doi.org/10.1016/j.landusepol.2015.08.002

Published in:

Land Use Policy

Document Version:

Peer reviewed version

Queen's University Belfast - Research Portal:

Link to publication record in Queen's University Belfast Research Portal

\section{Publisher rights}

Copyright ( 2015 Elsevier Ltd

This manuscript version is made available under the CC-BY-NC-ND 4.0 license http://creativecommons.org/licenses/by-nc-nd/4.0/) which permits distribution and reproduction for non-commercial purposes, provided the author and source are cited.

\section{General rights}

Copyright for the publications made accessible via the Queen's University Belfast Research Portal is retained by the author(s) and / or other copyright owners and it is a condition of accessing these publications that users recognise and abide by the legal requirements associated with these rights.

Take down policy

The Research Portal is Queen's institutional repository that provides access to Queen's research output. Every effort has been made to ensure that content in the Research Portal does not infringe any person's rights, or applicable UK laws. If you discover content in the

Research Portal that you believe breaches copyright or violates any law, please contact openaccess@qub.ac.uk. 
Evolving national park models: The emergence of an economic imperative and its effect on the contested nature of the 'national' park concept in Northern Ireland.

\begin{abstract}
National park models have evolved in tandem with the emergence of a multifunctional countryside. Sustainable development has been added to the traditional twin aims of conservation and recreation. This is typified by recent national park designations, such as the Cairngorms National Park in Scotland. A proposed Mournes national park in Northern Ireland has evolved a stage further with a model of national park to deliver national economic goals envisaged by government. This seeks to commodify the natural landscape. This paper compares Cairngorm and Mourne stakeholders' views on the principal features of both models: park aims, management structures and planning functions. While Cairngorm stakeholders were largely positive from the outset, the model of national park introduced is not without criticism. Conversely, Mourne stakeholders have adopted an anti-national park stance. Nevertheless, the model of national park proposed possessing a strong economic imperative, an absence of the Sandford Principle as a means to manage likely conflicts, and lacking any planning powers in its own right, may still be insufficient to bring about widespread support for a Mourne national park. Such a model is also likely to accelerate the degradation of the Mourne landscape. Competing national identities (British and Irish) provide an additional dimension to the national park debate in Northern Ireland. Deep ideological cleavages are capable of derailing the introduction of a national park irrespective of the model proposed. In Northern Ireland the national park debate is not only about reconciling environmental and economic interests but also political and ethno-national differences.
\end{abstract}

Key words: countryside commodification, national parks, contested identities, Northern Ireland, Cairngorms.

\title{
Introduction
}

The countryside has undergone rapid and fundamental change in the decades since World War Two. In tandem with the emergence of a global sustainability agenda (Ilbery and Bowler 1998) which sought to integrate agriculture with broader environmental and economic land uses (Cantore et al. 2011), a 'new countryside' has emerged characterised by a growing 'consumption' role (Cloke 1993; Marsden 1999). This is commonly referred to as a shift from production to post-production, or multi-functionality whereby productivist and post-productivist roles co-exist (Bjorkhaug and Richards 2008; Marsden and Sonnino 2008), or the emergence of a New Rural Economy (Shucksmith 2012). Woods (2011a: 91) explains: 'multi-functionality proposes that ... non-production benefits should be exploited as a source of revenue, by selling them as commodities to be consumed', and cites the exploitation of the amenity value of the countryside through tourism and recreational activities as one such example.

Rural commodification is a hallmark of the globalising countryside, the features of which are exhibited differently between rural locations, depending on the degree of penetration of globalisation processes' (Woods 2007: 494; Woods 2011b). The Northern Irish countryside, against the 'backdrop of 30 years of very limited growth and investment...' (DETI 2010: 1), was, in contrast to Scotland for example, sheltered from the forces of globalised tourism. However, with the Northern Ireland peace process came the opening of the Northern Irish countryside to the forces of globalised 
tourism. This has contributed to the rapid commodification of natural heritage, as evident from a recent surge in major tourism-related infrastructural developments (and proposals). For example, Carrick-a-Rede rope-bridge in the Antrim Coast and Glens AONB (originally constructed as an access point for local salmon fishermen) has been re-packaged as a product for tourist consumption. While the site is owned and managed by the National Trust, the initially free, unstructured and informal tourist experience has become a major pay-as-you-enter tourist attraction. In addition, a multimillion pound visitor centre was recently constructed at the Giant's Causeway World Heritage Site (situated within the Antrim Coast and Glens AONB); the price of parking at the visitor centre has proved particularly controversial (BBC, 2013; Magee, 2013). Meanwhile, as part of the Northern Ireland Assembly's drive to market a global golf product, permission was granted for a $£ 100$ million golf resort at Runkerry which is located adjacent to the Giant's Causeway (again within the AONB). This decision was highly contested and the development poses a threat to the site's World Heritage status (Stewart, 2013).

As rural places become 'theatres of consumption for tourists and visitors' (Woods, 2011a: 97-98), their multiple roles have given rise to numerous management challenges. These include reconciling competing economic, social and environmental interests whereby tension and conflict are perceived as inevitable between stakeholders who attach variable weigh to each (McCool 2009; McAreavey and McDonagh 2010). Maximising the economic potential of the countryside while at the same time maintaining or conserving the natural resource base is one such potential conflict. This dilemma can be conceptualised through the resource paradox (Plog 1974; Oliveira 2003; Williams and Ponsford 2009) or creative destruction idea (Schumpeter 2008; Mitchell 1998; Mitchell and de Waal 2009): natural areas, for example, offer a resource to be marketed, yet overuse (potentially through tourism) could destroy the natural beauty upon which the tourist experience depends, thereby jeopardising future tourism potential. In relation to natural areas, and national park locations specifically, Hamim (2002: 350) notes the possibility of 'loving our parks to death'.

This changing role of the countryside is paralleled by evolving models of national park. An original wilderness or conservation model has largely been replaced by a multi-functional model seeking to integrate a wider set of management objectives: conservation, recreation and sustainable development. Most recently the 'national park' label has, on occasions, been interpreted as a form of countryside branding and marketing intended to bring about the commodification of natural landscapes and rural space. This is most apparent in the recent (successful) Scottish and (unsuccessful) Northern Irish attempts to designate national parks. Scotland designated its first national park as recently as $\mathbf{2 0 0 2}$ while Northern Ireland remains the only part of the UK and Ireland without a national park. We argue that the model proposed for Northern Ireland (DoE 2011a) represents the most economically focused national park model seen to date. In this paper we examine the appropriateness of this proposed Northern Ireland model by drawing on the views of stakeholders within the proposed Mourne national park area and stakeholder experiences of Scotland's Cairngorm National Park model. The features of the Cairngorm National Park are closest to the proposed model for Northern Ireland (and the Mournes specifically).

The remainder of the paper is divided into six sections. First, we review evolving models of national park and argue that the model introduced in Scotland and proposed for Northern Ireland represent 
further evolutionary stages. Second, we outline the methodology adopted: namely, a series of interviews undertaken with stakeholders from the designated Cairngorms National Park (CNP) in Scotland and the proposed Mourne national park area in Northern Ireland. Third, we report on the local context and include a brief summary of past management strategies adopted in the Cairngorms and Mournes alongside ongoing local management issues. Fourth, we present the differing views between Cairngorm and Mourne stakeholders in relation to key features of the national park models: park aims, management structure and arrangements, and planning functions. Fifth, we compare the competing approaches to nationalism (as viewed through a national park lens) in Northern Ireland especially as a means to help explain the different stances between stakeholders in the Cairngorms and Mournes. Finally, we conclude with reference to two key queries. In terms of the evolution of the national park concept, we debate whether or not its latest transformation from a 'management and protection' designation to an instrument for 'countryside commodification' is a step too far (and abandons the underlying principles of national park designation). This is then followed by a somewhat pessimistic outlook regarding the future of national parks in Northern Ireland: namely, that even a widening of the aims and purpose of national park designation to incorporate a strong economic imperative may not overcome the unique obstacle of 'competing nationalistic identities' whereby the very term 'national' in national park is disputed.

\section{Evolving models of national park: towards an economic imperative.}

Figure 1 depicts, as a ladder, the key stages (and their principal characteristics) in the evolution of the national park concept from an essentially conservation and recreation focused designation to one that increasingly and more explicitly possesses a strong economic imperative. The ladder is not intended as a definitive categorisation of national park models, nor is there any suggestion that the higher rungs of the ladder represent a 'better' or 'worse' model; rather the ladder demonstrates the broadening of national park purposes and each rung represents a new (or evolving) stage on a continuum of national park models. According to Frost and Hall (2009: 11) '[t]his evolutionary process means that there is no single model of national park'.

The term 'national park' derives from the desire to preserve parks for the nation (Harroy et al. 1974). The first national park designation (and first rung on our ladder) - Yellowstone in the United States (1872) - stemmed from the threat posed to America's natural resources by the expansion of private property. It possessed a strong conservation and public enjoyment remit and placed the management of natural resources in the national interest by setting aside or nationalising extensive areas of pristine wilderness, typically devoid of human habitation for the benefit of the nation. The earliest and original interpretation of national parks was, therefore, as wilderness areas: a nature 'apart' from or 'in spite' of society (Barker and Stockdale 2008).

The model fits the IUCN Category II definition of national park as summarised by Goldsmith and Warren (1993: 210): 'ecosystems not materially altered by human activity, of great beauty and of great scientific interest, where human exploitation and occupation are removed and visitors only allowed to enter under very controlled conditions'. The legacy of this wilderness approach has, according to the IUCN (2002), been the development of conservation islands and a distorted appreciation of the relationship between society and nature. These have made this model of national park unsuitable for most of Europe (Barker and Stockdale 2008) and as a consequence 
evolving models of national park have facilitated the global application of the national park concept. In doing so, national parks have evolved as mechanisms for the delivery of sustainable development (Dower 1999) and have sought to reconcile the relationship between society and nature by incorporating conservation and socio-economic development aims (Holdgate 1992). For example, Our Common Future (WCED 1987) called for national conservation mechanisms to integrate environmental protection with economic development, and the creation of Category $\mathrm{V}$ 'protected landscapes' designations by IUCN facilitated the delivery of sustainable development within protected areas (IUCN 2002). Category V designations are places where '... the interaction of people and nature over time has produced an area of distinct character with significant aesthetic, ecological and/or cultural value, and often with high biological diversity' (IUCN 1994: 22). While only Category II designations are explicitly referred to as national parks (by the IUCN), the IUCN acknowledge that the term national park may be used in some countries for other categories of protected area (including Category V). 


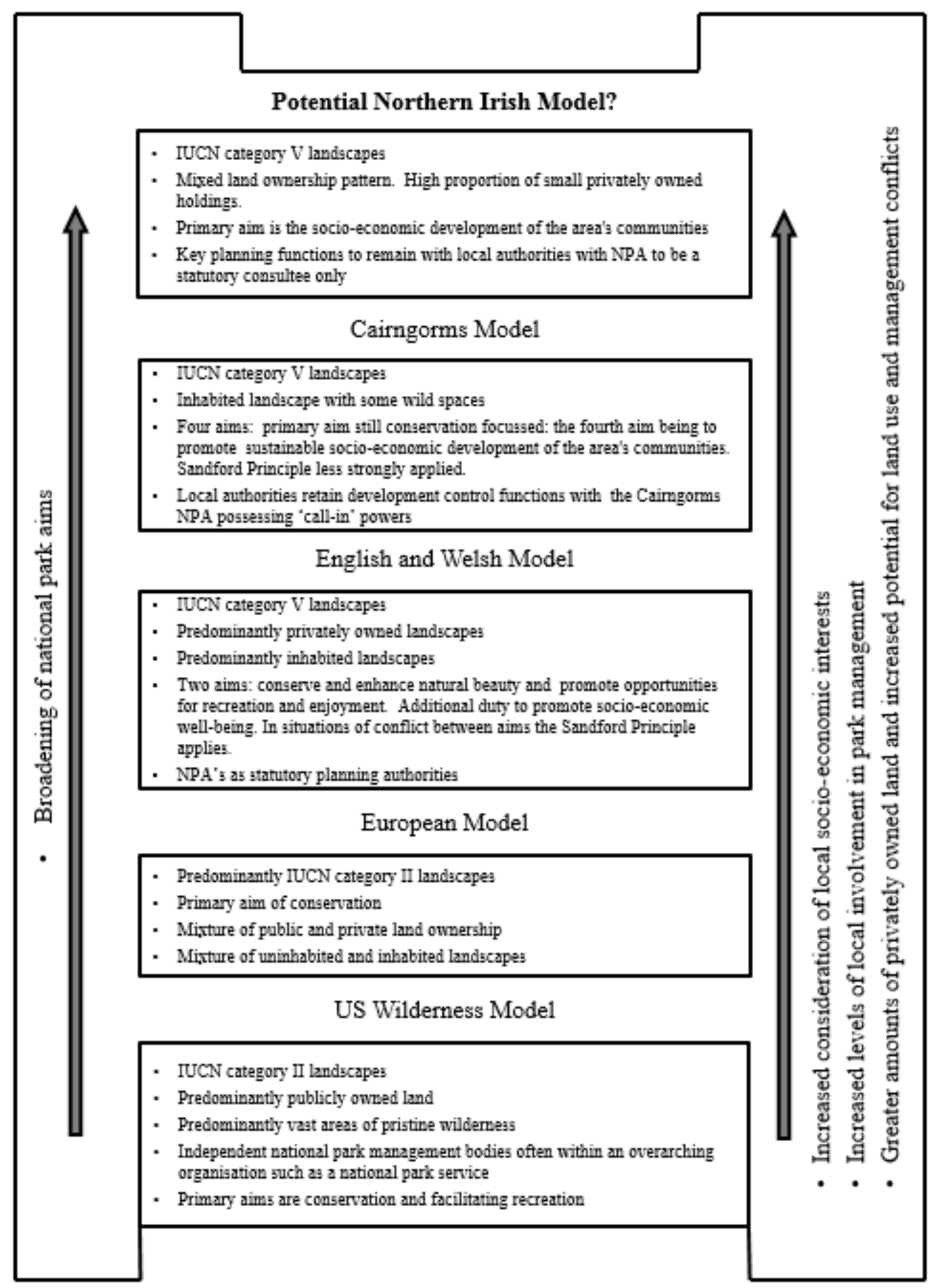

Figure 1: A ladder of national park models 
A multi-purpose model of national park (combining nature and society) represents the second rung on our ladder (Figure 1) and is typified by national parks in Europe (Mayer et al. 2010). Although taking many forms (Bishop et al. 1998), this model relates to a broader set of management objectives in a largely inhabited and cultivated countryside where conservation goals are frequently compromised by 'incompatible development or ownership' (Bishop et al. 1998: 4). Even though this European model encompasses a multi-purpose approach it continues to possess an 'overriding emphasis on environmental management, protection and enhancement' (McCarthy et al. 2002: 667). Social and economic aims are therefore secondary to conservation with land use zoning typically used to minimise potential land use conflicts. For example, a highly restrictive central protection zone is surrounded by peripheral zones where some development and recreational activity is permitted (Bishop et al. 1998; McCarthy et al. 2002).

The third rung on the ladder (Figure 1), and therefore a third model of national park, has been developed for the inhabited (IUCN (2008) Category V) landscapes of England and Wales. Following the National Parks and Access to the Countryside Act (1949) national parks were designated in England and Wales with two statutory aims: to conserve natural beauty, wildlife and cultural heritage and to promote opportunities for understanding and enjoyment. They were introduced in response to fears about a lack of public access and unplanned resource development (forestry, new housing). This remained the model of national park in England and Wales until the mid 1990s when, influenced by the development of the sustainability agenda, the Environment Act (1995) (and more recently the Natural Environment and Rural Communities Act 2006 in England) placed a duty upon national park authorities to 'seek to foster the economic and social well-being' (McCarthy et al 2002: 668) of national park residents. While this did not amount to an additional explicit socio-economic development aim for national parks, it did in effect, give greater prominence to development within national parks but, importantly, not at the expense of conservation: the Environment Act (1995) endorsed the Sandford Principle (McCarthy et al 2002) whereby in situations of conflict between the park aims, greater weigh should be given to 'conserve natural beauty, wildlife and cultural heritage'. Because of the adoption of the Sandford Principle this model of national park, according to Locke and Dearden (2005), only narrowly fulfils the definition of a protected area. Furthermore, a DEFRA Circular (2010: 5) presents a strong sustainable development vision for English national parks: by 2030 they will be places where '[s]ustainable development can be seen in action'.

The increasing prominence given to sustainable development went a step further (fourth rung of Figure 1) in the model of national park introduced in Scotland (where two national parks have been designated to date: Loch Lomond and the Trossachs (2002) and the Cairngorms (2003)). Notably four aims are enshrined in the National Park (Scotland) Act 2000. To the twin aims of the English and Welsh model were added 'promotion of sustainable use of natural resources' and 'promotion of the sustainable economic and social development of the area's communities'. This signalled a firm legislative commitment to sustainable development. Broadly the aims are compatible with IUCN Category V protected areas management guidelines (IUCN 2002). In common with England and Wales, the Sandford Principle is applied and included in the Scottish legislation to ensure that in situations of irreconcilable conflict between the four aims, greater weigh is given to the first 'to conserve and enhance the natural and cultural heritage'. However, the contrasting approach to local socio-economic development within national parks in England/ Wales and Scotland is typified by recent planning decisions. In (Scotland's) Loch Lomond and the Trossachs National Park the re- 
opening of a goldmine was approved despite significant concerns by the conservation lobby (Scott 2011). Meanwhile, in England, a proposal for a tourist zip line in the Lake District National Park was refused on the grounds that, despite economic benefits, the proposal would cause unacceptable harm to the special qualities of the landscape (Lake District National Park Authority 2011).

The growing emphasis on economic considerations and local community participation within UK national parks reflects the 'new conservation' paradigm; a 'manifestation of neo-liberal ideology' viewing the 'market as the saviour of biodiversity' (Brown 2002: 7). In this context, a fifth rung on the ladder is apparent in a recent Northern Ireland White Paper on Proposed Enabling Legis/ation for National Parks (DoE 2011a). It is not situated within a traditional conservation agenda or even alongside existing rungs on the national park ladder. Instead, the most recent model of national park represents a significant move towards a model which gives unprecedented prominence to economic development. It sits in stark contrast to the traditional conservation values that underpinned the founding of the national park concept some 150 years ago. This added economic focus has emerged within a specific set of socio-economic circumstances in Northern Ireland. With economic growth stunted by several decades of sectarian conflict and violence (DETI 2010), the devolved Government (Northern Ireland Assembly) has identified growing the Northern Ireland economy as its top priority (NIE 2008; NIE 2012). The countryside is viewed as an important facilitator of tourism based growth: '[t]ourism in Northern Ireland depends largely on the quality of the countryside, its natural attractions and its distinctive cultural heritage and many visitor destinations are within AONBs' (Northern Ireland Environment Policy Group 2004: 9). Notably, the Northern Ireland Economic Strategy (NIE 2011) refers to national parks under a heading of 'business growth' and identifies the establishment of national parks legislation as one of several key actions for developing economic infrastructure. This desire to develop an economic orientated model of national park is emphasised throughout the White Paper (DoE 2011a):

'.. we seek recognition of our most cherished landscapes through the national park label, while utilising it as an economic driver that will boost local business and provide sustainable employment and new business opportunities for this and future generations' (Foreword by Minister of the Environment).

'A key argument for national parks in Northern Ireland is the need to grow the economic opportunities of our most cherished landscapes ..... . There is a need for national parks to boost tourism ... and to contribute to growth generally. .... National park designation would increase focus and marketing opportunities for tourism in an international context. This would increase visitor numbers and spend in any designated area' (p. 4).

Supporting evidence was provided by Buchanan (2006): ten years on from designation a Mourne national park could generate an additional $f 81 \mathrm{~m}$ per annum in tourism revenue and support 4700 additional jobs within the park boundary and surrounding areas.

Commodification of the Northern Irish countryside is implied through national park designation: 'National park status would add value to an area's economic and social opportunities by giving it an internationally important profile which would attract more visitors and investment, and provide a branding opportunity for the area's produce' (DoE 2011b: 27). Minimal reference is made to the environmental merits of national park designation, nevertheless, the White Paper does acknowledge 
the need to strike a balance between conservation and economic development (if only to manage the potentially resulting resource paradox):

'Some of our iconic landscapes suffer from unmanaged visitor pressures ... designation would help to address these issues and also facilitate conservation and enhancement of ecosystems, so that these landscapes remain attractive to visitors and make a positive contribution to the livelihoods and welfare of the people who live and work in and around them' (p.4).

Like in Scotland, the proposed model of national park for Northern Ireland possesses four aims. However, in contrast to Scotland, and indeed elsewhere where the first aim of any national park is normally conservation orientated, the proposal in Northern Ireland lists the first aim as 'promotion of sustainable economic and social development of the area's communities' (DoE 2011a: 8). Furthermore, to deliver the Park aims a national park management body is envisaged which 'would be able to initiate, facilitate and encourage development' (DoE 2011b: 7). These features demonstrate that a socio-economic imperative is at the forefront of government thinking on national parks, and has raised fears with Northern Ireland's conservation lobby that national parks will be 'rural development zones' (Northern Ireland Environment Link 2011: 7).

In 2013 the Northern Ireland national park proposal was withdrawn (due to political hesitancy in the face of perceived local opposition). Nevertheless, the Environment Minister emphasised that he is 'not scrapping national parks' but instead 'putting plans to introduce national parks in Northern Ireland on hold' (BBC News Northern Ireland 2013). This then is unlikely to be the end of either the national park debate in Northern Ireland or the emergence of a strong economic model of national park. Indeed, in the same month as the Northern Ireland proposals were withdrawn a report was published which highlighted that Wales' three national parks attract more than 12 million visitors, who spend $f 1$ bn a year:

'In many ways the remit of the National Parks - pursuing the economic and social wellbeing of communities alongside environmental management - is a thoroughly modern concept [our emphasis] that fits well with the Welsh Government's approach to sustainable development. In this sense, the Parks are 'exemplars of sustainable development" (Arup for National Parks Wales 2013: 9).

Even though Northern Ireland remains the only region of the UK without a national park, the recent proposal represents a significant 'next step' in the global evolution of national parks: one that places a greater emphasis on sustainable development and overtly views designation as a mechanism for delivering national economic goals. This strong economic imperative seeks to commodify and brand highly valued landscapes. Conservation aims are becoming secondary to, or are used as a means to manage such landscapes for, the delivery of an economic agenda rather than to deliver landscape protection in its own right. In the remainder of this paper, we ask whether this model or 'thoroughly modern concept' is likely to lead (at some future stage) to the introduction of a national park in a region where to date stakeholders have been vehemently opposed to national park designation.

\section{Methodology}

This paper compares stakeholder views on the models of national park introduced in the Cairngorms (Scotland) and proposed for the Mourne Area of Outstanding Natural Beauty (AONB) in Northern 
Ireland. Both models possess a strong economic remit, with the Cairngorms National Park the closest (rung on the national park ladder) in terms of its park aims, management structure and arrangements, and planning functions to that proposed in Northern Ireland. The analysis also contrasts (in a Northern Ireland context) competing national identities, which it is argued represent a significant obstacle to the delivery of national parks in Northern Ireland (irrespective of the model proposed).

A case study approach facilitated an intensive examination of the Mournes, whilst also allowing comparative findings to be drawn from the Cairngorms. By analysing across contexts 'we increase our chances of being able to use that very detail not only to understand how things work in specific contexts, but also how things work differently or similarly in other relevant contexts' (Mason 2002: 125). A qualitative research approach enabled the researcher to 'get closer to the actors perspective' (Denzin and Lincoln 2005: 12). This consisted of a series of semi-structured interviews taking the form of thematically guided conversations (Yin 2003) with Mourne and Cairngorms stakeholders. All were involved in post-devolution (that is, since 1998/1999 with the devolution of specific powers from Westminster to Edinburgh and Belfast) consultation processes intended to lead to the introduction of a national park in both areas. Interviewees were identified from existing documents and contacts, and through referral (Valentine 2005) in scoping interviews with key informants (conservation representatives, management body representatives and landowners). While an attempt was made to select a representative range of stakeholder interests, a 'representational sample' was not pursued. Instead, we sought to include as broad a range of stakeholders from as many different professional and organisational backgrounds as possible. This included individuals of 'particular interest' or 'expertise' (for example, Kathleen Rettie, a national parks expert) and anyone who had been involved in the consultation processes either as an individual participant, a representative of a stakeholder grouping, an event co-ordinator, organiser or observer. The interview profile included elites (such as politicians), general members of the public and those who were/were not affiliated to a formal stakeholder organisation. Interviewee selection was also influenced by emerging lines of inquiry. For example, an apparent link emerged between ethno-national allegiances and local opposition towards a Mourne national park, and accordingly stakeholders with competing ethno-national identities (Nationalist and Unionist) were included in the Mournes interview sample.

A total of 41 interviews were conducted (21 in Mourne and 20 in the Cairngorms) and included representatives from: park user groups, residents groups, Cairngorm National Park Authority/other management bodies, the farming lobby, conservation groups, local and central government, as well as politicians and local trustees, estate owners, tenant farmers, owner occupied farmers, local business owners and local residents. Each interview lasted no longer than two hours and, with the interviewee's prior consent, was digitally tape recorded. The broad themes explored at interview included: the historical absence of national parks in both countries; the relationship between political devolution and the national park agenda; land management challenges and approaches adopted; local support and opposition; the consultation process, stakeholder involvement and power differentials; actual and proposed (in Northern Ireland) national park aims and management structures/ features; balancing environmental and economic interests and the emerging economic context; and perceived actual and potential (in Northern Ireland) benefits arising from national park designation. 
While the Cairngorms interviews were conducted from a post designation perspective, the Mourne AONB represented a case in progress (no formal decision had been taken about whether or not to designate a national park) at the time of interviewing. As a 'live' issue in the Mournes stakeholder views were expected to be more emotive. Whereas, several years since designation, memory recall was a potential problem among Cairngorms interviewees, alongside the fact that stakeholder perspectives were likely to have evolved (consciously or subconsciously) based on their personal post-designation experiences. The views of those who were originally opposed to a Cairngorm National Park may have mellowed based on experience of how the park operates; conversely, those who were supportive at the time of designation may now question the value of a national park. Given the mainly positive views reported (Forsyth et al. 2001; Rettie 2001) immediately following the Cairngorms consultation process the invitation now for interviewees to speak on 'reflection' following actual designation provided further insights into the model of national park introduced.

All 41 interviews were transcribed. A thematic analysis followed with the software package NVivo9 used for organising the reconstruction of the data set.

\section{The Local Context}

The introduction of national parks in both Scotland and Northern Ireland has been debated for some time. In Scotland national parks were first included as a recommendation in the Ramsay report (1947), but landowner opposition meant this did not lead to national park legislation. At the same time the Northern Ireland Planning Advisory Board (1947: 10-11) 'unanimously and urgently recommend(ed) that some areas be scheduled as National Parks'. Other political priorities (dealing with civil unrest), strong landowner opposition and political lobbying from farming organisations quashed any prospects of designation at the time (Buchanan 1982; Mitchell 1999). Prospects for their introduction in both jurisdictions, however, received renewed impetus with the devolution of specific powers from Westminster to Edinburgh and Belfast (1998/1999): see Bell and Stockdale (2015a). Indeed national park designation was adopted as one of the first policy agendas by both devolved administrations.

The Mournes and Cairngorms are multi-functional and environmentally significant landscapes comprising distinct social, economic and environmental functions. Both are IUCN Category V landscapes, inhabited, predominantly privately owned with a legacy of recreational activity and tourism. However, the landscapes possess distinct differences (summarised in Table 1).

Despite the large tracts of wild land, the Cairngorms is a working landscape with a rich human history (Warren 2009). The local economy combines traditional private estate activities with recreation, tourism, environmental stewardship and a growing service-orientated economy (MacKay 2005): tourism-related businesses now account for 30 percent of the Cairngorms economy (CNPA 2010). The Cairngorms, however, also has a long history of land use conflict (Watson 1980; Lambert 2001; Gimingham 2002; Warren 2002). According to Coppock (1980) there is nowhere in the UK where the conflicts between tourism/recreation and conservation are more apparent. These were such that the Countryside Commission for Scotland (1990) recommended the introduction of a national park but opposition suppressed the campaign. Instead, further site specific designations 
(SSSI's, SPA's, SAC's) were applied to the Cairngorms alongside the creation of a Cairngorms Working Party (in 1991) to develop a management strategy and discuss the administrative changes necessary to achieve integrated management (Cairngorms Working Party 1993). This was followed by the setting up of a Cairngorm Partnership (in 1994) to bring together all public agencies and local authorities to develop and implement an integrated management strategy (Rettie 2001).

Table 1: A comparison of the local landscape context between the Mournes and Cairngorms

\begin{tabular}{|c|c|c|}
\hline Feature & (Proposed) Mournes National Park & Cairngorms National Park \\
\hline Size & $570 \mathrm{~km}^{2}$ & $4528 \mathrm{~km}^{2}$ (i.e. largest in UK) \\
\hline Population & 54,000 approx. & 17,000 approx. \\
\hline Existing designations & AONB, ASSI, NNR, SAC, SPA, & $\begin{array}{l}40 \text { percent of area is covered by other } \\
\text { conservation designations (SSSI, SPA, } \\
\text { SAC). }\end{array}$ \\
\hline Local Authorities & $\begin{array}{l}3 \text { District Councils: Newry \& Mourne, } \\
\text { Banbridge and Down. }\end{array}$ & $\begin{array}{l}5 \text { Local Authorities: Highland \& Islands, } \\
\text { Aberdeenshire, Moray, Angus and } \\
\text { Perth \& Kinross }\end{array}$ \\
\hline Annual visitor numbers & 150,000 per annum & 1.4 million per annum \\
\hline Population density & High & Low \\
\hline $\begin{array}{l}\text { Highest level of } \\
\text { landscape designation }\end{array}$ & AONB & National Park \\
\hline Key employment sectors & Agriculture and tourism & Sporting estates and tourism \\
\hline Main landscape pressures & $\begin{array}{l}\text { Tourism induced pressures, one-off } \\
\text { housing, wild fires, overgrazing }\end{array}$ & $\begin{array}{l}\text { Overgrazing, bulldozed tracks, } \\
\text { expansion of settlements and downhill } \\
\text { skiing }\end{array}$ \\
\hline $\begin{array}{l}\text { Land ownership and } \\
\text { public } \\
\text { arrangements }\end{array}$ & 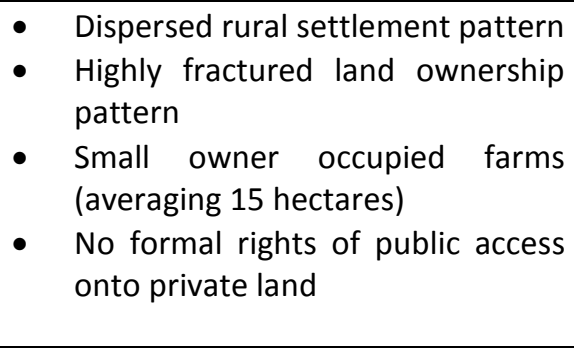 & $\begin{array}{l}\text { - Highly concentrated land } \\
\text { ownership pattern. } \\
\text { - Tradition of public access } \\
\text { formalised through legislation } \\
\text { (right of responsible access) } \\
\text { - Landed estates cover } \\
\text { approximately 75\% of the Park } \\
\text { area (CNPA, 2012) }\end{array}$ \\
\hline Land management legacy & $\begin{array}{l}\text { Mourne Heritage Trust (1997). } \\
\text { Landowners were critical of the Trust. }\end{array}$ & $\begin{array}{l}\text { Cairngorms Working Party (1993) and } \\
\text { Cairngorms Partnership (1994). } \\
\text { Landowners provided positive } \\
\text { reflections of the Cairngorms } \\
\text { Partnership in particular. }\end{array}$ \\
\hline Other key context factors & $\begin{array}{l}\text { Distinct ethno-nationalities } \\
\text { sectarian geographies }\end{array}$ & $\begin{array}{l}\text { Legacy of feudal land ownership - } \\
\text { hierarchical social structure }\end{array}$ \\
\hline
\end{tabular}

The Mournes (located in the South East of Northern Ireland) is an area where weather, geology and human activity have interacted to create a unique landscape: a granite massif, upland heath, forest, blanket bog, farmland and a maritime environment (MHT 2007). The area sustains traditional industries such as agriculture, fishing, forestry and small scale quarrying: 53 percent of the land is actively farmed. It is also an important tourist area attracting approximately 150,000 visitors per annum and contributing $f 38 \mathrm{~m}$ to the local rural economy (Buchanan 2006). However, the importance of tourism brings with it a particular set of difficulties: gates left open with livestock straying, the destruction of dry stone walls, malicious fires, increased littering, path erosion, and disturbance to wildlife (CAA Network 2007; Mourne Heritage Trust 2007; Mourne Trustees 2010). The area is also prone to speculative house building (DoE 2000; Mourne Heritage Trust 2007) with 
over 4,000 planning applications for single houses in the countryside approved between $2002 / 3$ and 2012/13. The sale of house building sites has represented an important source of income for local farmers. As a result of these many management pressures a Mourne Heritage Trust (MHT) was established in 1997 as a management body specific to the Mourne AONB. It proposed a 'Celtic national park' for the Mournes (Mitchell 1999) and in response government (namely; the Environment Minister) established a Mourne National Park Working Party (MNPWP) tasked to examine possible national park boundaries, develop proposals for a possible management structure and conduct a formal public consultation process in the area (MNPWP 2007).

The eventual introduction of national parks in Scotland followed a preliminary national parks consultation process covering all of Scotland which informed the preparation of detailed proposals (Scottish Natural Heritage 1999) and in turn a Draft National Parks Bill. This work had been completed prior to the establishment of the Scottish Parliament with the Bill subsequently passed as the National Parks (Scotland) Act 2000. Prior, therefore, to any local consultation in proposed national park areas Scotland had already undertaken a national consultation process and had legislation in place which contained details of the model of national park to be introduced and its operational arrangements. It was only when this was in place that a locally specific Cairngorms consultation process was initiated and carried out by Scottish Natural Heritage (SNH). In contrast, no Northern Ireland-wide consultation preceded a locally specific 2006 Mournes national park consultation and there was no National Parks Act or White Paper at the time. Some of the flaws in the policy process delivered in Northern Ireland can be attributed to the governance context at the time. For example, the suspension of the Northern Ireland Assembly and the influence of Direct Rule Ministers were shown by Bell and Stockdale (2015a) to have disrupted the policy process by delaying the drafting of legislation. As a consequence, the Mourne consultation suffered from a lack of information as to the model of national park that might be implemented. These varying legislative contexts, amongst other issues, contributed to Cairngorm and Mourne landowners adopting differing stances during consultation (Bell and Stockdale 2009; 2015b). While Cairngorm stakeholders were positive and chose to engage constructively in the process, it fuelled suspicion and fear among Mourne stakeholders who adopted an anti-national park stance from the outset. Indeed, detail as to the model of national park proposed for Northern Ireland (and the Mournes) only emerged with the publication of a White Paper on Proposed Enabling Legislation for National Parks (DoE 2011a), some five years after the Mournes consultation ended.

\section{Examining stakeholder perspectives}

The Cairngorms National Park model differs from previous models by at least three distinct features: national park aims, management structure and arrangements, and planning functions. This combination of factors has led some conservationists to deem the Cairngorms unworthy of the national park label (Watson 2003; Bailey 2010; Edwards 2010). Similar, as well as some further evolutionary, features (Figure 1), have been outlined for Northern Ireland which allows for direct stakeholder comparisons between the Cairngorms and the Mournes. In particular, we ask if the model of national park detailed in the Northern Ireland White Paper (DoE 2011a) is likely to lead to a more supportive national park stance in the Mournes. 
In contrast to the normal practice of placing conservation as the primary aim of national park designation, the Northern Ireland White Paper lists (for the first time) 'promotion of sustainable economic and social development of the area's communities' as the first aim. This was perceived by some Mourne farmers as a notable shift in emphasis and one that may alleviate some local hostility towards a national park:

"I think with the first aim being social and economic I am now less concerned about a national park turning this area into a countryside museum. If these aims had been set out at the very beginning [of the 2006 consultation] it could have been a different story all together. But I now think it's too late to convince a lot of the farmers; the damage has been done" (Mourne farmer).

Others, however, remain unconvinced:

“it doesn't matter what way they dress it up with aims and all the rest, we don't need a national park here" (Mourne farmer).

In Scotland, the first aim is conservation orientated with its unprecedented third and fourth aims relating to sustainability (of natural resources and the area's communities). Notwithstanding this, the Cairngorms National Park Authority (CNPA) has adopted a clear socio-economic focus as reported during respective interviews with a former CNPA Board Convenor and CEO:

"What the Park is trying to do is demonstrate that conservation is social and economic. Conservation is not an end in itself and the reason why we wish to conserve these places is because if we conserve them people will be able to enjoy them and make more money out of them. The purpose of conservation is human, the more people benefit economically from people coming into the Park, the more they will benefit...".

"Suspicion at the beginning revolved around the concern that the environment would hold sway and there would be no economic development and therefore it was important when we [CNPA] came into existence to bend over backwards to show that was not the case".

The inclusion of an explicit sustainable development aim in Scotland does appear to have been an attempt to demonstrate that economic and conservation goals are compatible:

"Just because you are looking after the communities and businesses does not mean you are not looking after the environment, because $75 \%$ of land is in private ownership we have to look after the communities and the farmers because they are looking after the land" (Former Convenor of CNPA Board).

Others saw it as the continuation of a long standing feature of Cairngorms management:

"we [the business community] were operating the four aims of management long before there was a national park...it is ideal because there is widespread understanding in the business sector that our livelihood depends on maintaining the environment" (Business owner).

Meanwhile, conservationists in particular were highly critical: 
"I come back to the point the primary legislation on conservation is quite weak...they use that [the four aims] as an excuse to do what they want. Even in SNH [Scottish Natural Heritage], at a very high level, there is recognition that national parks are not conservation models ... fundamentally national parks in Scotland are not a conservation designation" (Cairngorms conservationist).

Such a view is supportive of Watson (2005: 1) who with reference to conservation describes the Cairngorms as 'one of the world's worst' national parks. However, the Scottish legislation, does incorporate the Sandford Principle which, at least on paper, gives priority to conservation should there be a conflict between Park aims. There is no mention of the Sandford Principle in the Northern Ireland White Paper. Instead, priority is given to the delivery of sustainable development: '[t]he expectation is .... to balance the needs of communities with the needs of the environment by pursuing a goal of sustainable development' (DoE 2011b: 33). As a consequence conservation organisations fear an over-emphasis on social and economic development (Northern Ireland Environment Link 2011).

\section{Management arrangements and structure}

The Northern Ireland White Paper outlines possible institutional arrangements for governing national parks; the preferred option being local independent bodies for each park (as in Scotland, England and Wales) instead of district council (i.e. local authority) management. Notably this preference is explained in terms of such bodies being best placed to deliver landscape protection (and, therefore, a conservation aim); but it is unclear whether this is for conservation's own sake or as a means to manage any potential resource paradox arising from this strong economic model of national park:

'It [the creation of independent management bodies] would allow the management body to focus in-depth on the clear and specific functions and purposes which lie at the heart of landscape protection. ....the need for councils [local authorities] to manage their wider remit may stifle the adoption of the flexible, responsive and innovative approach which parks in Britain have been able to employ to the benefit of parks' communities and their landscapes' (DoE 2011a: 9 and 13).

An independent management body in theory should offer a more holistic and integrated approach to negotiate competing countryside interests (and as shown later, opposing national identities). However, a new management body may not receive widespread acceptance. While some Mourne farmers endorsed enhanced management arrangements:

"the way the land is deteriorating, we need a better management body, enhanced management is definitely required".

Others were fervently opposed to perceivably being told what to do by an expensive and unelected body:

"they want a management body, another quango with perhaps $21 / 25$ people...the area is already being managed by those who work it, they don't want anyone else coming telling them what to do...if there were management issues...DARD [Department of Agriculture and Rural Development] or DoE [Department of the Environment] could work with the farmers 
who own land, why do we need a middle man? it always costs more money" (Mourne farmer).

'this [a national park authority] would be an autonomous body with far-reaching powers...no-one wants to be ordered about by an unelected quango' (Mourne Area of Outstanding Natural Beauty Residents' Action Group 2011: 4).

Given the predominance of privately owned land in the Mournes, landowner compliance, in particular, will be essential to fulfilling park aims. In light of the fervent anti-national park sentiment amongst certain Mourne landowners, securing their 'buy in' to any new management arrangement will be difficult. In addition, broader stakeholder representation on the national park board will be necessary, including the creation of other participatory forums to engage all stakeholder interests. If a management body is to gain acceptance from the less obdurate sections of the local community, the ethos and governance structures adopted, make-up of the Board and powers that it possesses will be important.

The White Paper makes clear that a management body would not adopt a 'regulatory regime but a facilitating and enabling framework' (DoE 2011a: 8). This resonates with the partnership philosophy of the CNPA (Stockdale and Barker 2009; Dinnie et al. 2012). According to a CNPA official, the CNPA has sought to act as an:

"enabling body ... [with an] ethos of not doing things but coordinating action through existing people or organisations".

However, a series of challenges could serve as 'impediments to inclusion' (Stockdale and Barker 2009: 489) and effective governance within a Mourne national park. First, in order for a national park management body to respond effectively to local needs and desires, a genuine commitment to stakeholder involvement is required. Stakeholder forums, which represent one mechanism for involving the community in day-to-day national park management, have been used in the Cairngorms; CNP farmers, while appreciative of the philosophy behind a Farmers' Forum, for example, were nevertheless critical of how it operates in practice:

"They have recently set up a Farmers' Forum which is reasonably well attended and it's a good idea. However it's not the same as before [during the time of the Cairngorms Partnership], I don't see that they have actually delivered much through the Forum";

"The park is split by a big mountain range so by trying to please everybody they have the meeting in the middle, at the Lecht, .... that's too far from me ... so that's why I haven't [attended]".

The first quote suggests that the perceived success of the CNPA's partnership approach has been tainted by post-national park designation experiences and that tangible outcomes/benefits for participants are required to enhance the long-term success of any regular participatory mechanism. The second quote acknowledges that the physical geography of a national park has the potential to inhibit involvement (Stockdale and Barker 2009). The reality of geo-political division in the Mournes (discussed below) should also be considered when choosing the location of any participatory events. 
Awareness of the politics of space and identity is required to help facilitate cross-community involvement; for example by selecting neutral meeting venues (Shortall and Shucksmith 2001).

A second challenge may be to establish a common strategic vision amongst disparate Mourne stakeholders and achieve a consensus on the best way to fulfil this vision. The requirement to achieve multiple aims and accommodate diverse stakeholders within the CNP has reportedly generated confusion and a lack of shared understanding about what the national park is, who it is for and how it should be managed (Dinnie et al. 2012). One tenant farmer explained:

"I don't really know what the national park has done for me or in fact anyone. I would like to see farmers get some grants which we thought would happen but [it] hasn't. I think we are seen as a nuisance....maybe businesses here have benefited and maybe it was intended to help them all along I just don't know."

Existing rivalries and tensions between Mourne stakeholders were heightened during the 2006 national park consultation which suggests that the pre-conditions for effective engagement and collaboration have been somewhat eroded (Bell and Stockdale 2015b). The prevalence of private landowners means that a Mourne national park will depend on management by consensus, with a management body acquiring limited powers to make things happen. This has implications for the effectiveness of national park management. The issue of national park rangering is a good example: introducing a network of rangers (as in English and Welsh national parks) may help to minimise/address localised landscape pressures (such as those presented by tourism) (UK Association of National Park Authorities 2013). But, the CNPA does not operate a dedicated ranger service, instead favouring collaboration with existing private estate ranger services and other public and private bodies. A majority of stakeholders interviewed supported this unimposing form of management:

"while there can be the odd dispute or difficulty [with private estate ranger services], on the whole this ethos of encouraging other people, with us acting in a coordinating function, is very powerful and effective, it also offers great value for money for the public" (CNPA Official).

However, the approach was viewed dimly by conservation interests who alleged that economic goals will always prevail:

"I can't understand the fact they [the CNPA] don't have their own ranger service. It's a complete disaster to put all your eggs in the basket of private and other public bodies, you have no control, you are at the mercy of economic interests."

Equally, interviewees acknowledged a problem with a dedicated national park ranger service:

"I mean what does a ranger do, once again he has no authority, this is private land. So if he goes to this quad biker and says get off the mountain, the guy could equally say bugger off...you see a ranger will have no authority whatsoever."

Given current public access arrangements (there are limited rights of way in the Mournes; public access to private land is de facto in nature, granted by custom rather than legal right) and the dominance of private land ownership in the Mournes the success of a ranger service would depend 
on landowner compliance. Incentives, to encourage Mourne landowners to engage in a consensual ranger service and assist in the delivery of shared management objectives, are likely to be required.

Finally, the success of any partnership is enhanced through its effectiveness in achieving tangible results (Stockdale and Barker 2009); a mismatch between expectations and outcomes can reduce support for partnership arrangements (Shortall and Shucksmith 2001). Members of the MNPWP and individuals who participated in the 2006 consultation stated their reluctance to engage in future governance processes due to the lack of outcomes from their previous involvement:

"I went along to several meetings and responded to the leaflet and the government don't even tell us what the heck's going on" (Mourne resident).

When asked if they would attend another national park related consultation this Mourne resident responded:

"probably not, it would be a shouting match anyway and I would be better spending my time doing other things."

Meanwhile, Cairngorm farmers specifically voiced dismay at how their financial expectations of a national park have not been met. Reflecting on the lack of real benefits since designation, some disclosed feelings of being misled or 'conned':

"Was there a big conspiracy? There probably was, was it all [the partnership, consultation] just an attempt to lure us [the farming community] into a false sense of security and then it was a rollercoaster that we couldn't stop?"

"We haven't had any financial reward for the environmental benefits we have delivered to the public".

Others questioned the branding and marketing value of the Park for local producers:

"There is the farmers' market but not everybody can turn up and sell Cairngorm beef or lamb ... there is a limit [to the number of stalls], so what about the other 380 farmers who have something to sell?"

Delivering tangible outcomes for local stakeholders in the early years of operation would seem a necessity if a more supportive stance towards a Mournes national park is to be developed. Indeed developing an empowering ethos, establishing avenues for local involvement in park management and genuinely committing to work in partnership with others to achieve park aims could reduce opposition. As one national park opponent conceded:

"if it [national park] was one that could be constructed that could act as a catalyst for locally empowered management it could be [accepted]".

However, in light of local suspicion towards a national park management body (Bell and Stockdale 2009) - perceived by some as an "autonomous and unelected quango" - the proportion of local representation on the national park board could influence the level of support for a management body. As is typical of most UK national parks, the Northern Ireland White Paper (DoE 2011a) recommends that any management body should be controlled by a national park board. It proposes 
a board of no more than 20 people: 20 percent park inhabitants, 40 percent local district council nominees and 40 percent Ministerial appointments. Landowners, however, call for even greater local representation:

"We own 75\% of the land within the [Mourne] AONB; we would need 75\% representation on the board ...."

Local interests, but not exclusively landowning interests, are heavily represented on the CNPA Board:

"We sometimes struggle to convey to people how local the Board is, I would say nearly 15 out of the 19 live in the boundary of the park or maybe just outside it, so there's maybe only four from outside" (CNPA official).

As in the Cairngorms, majority local representation on a board is likely to be required if a Mourne national park is to gain local acceptance. The White Paper cites direct elections as one possibility for appointing local members and is used by the CNPA. These stakeholders were supportive of such elections:

"I think they [Board elections] are working quite well, I am still surprised by the level of engagement and the number of people standing in elections...the turnout [for the elections] is probably not as high as the National Park Authority would like but I think in the general scheme of things it's a good arrangement" (CNP business owner);

"The Board is very good actually, it has a very good balance, with the elections you had people you would find on the street which is very good" (CNP estate owner).

Achieving the necessary balance on a Board for the Mournes will not only require acceptable representation in terms of local/ national interests or between different stakeholder interests. There is an additional Northern Irish dimension to board representation that will need to be guarded against: voting patterns remain largely sectarian (Knox 2012). This point is returned to when discussing competing national identities below.

\section{Planning functions}

Development control/ management powers are a vital regulatory function of most UK national park authorities with the Cairngorms representing the one notable exception in a UK context (it is also different from the Loch Lomond and Trossachs National Park in Scotland). Development control arrangements in the CNP have remained with the local authorities, with the CNPA possessing only 'call in' powers for the largest and most controversial planning applications. This unique system was devised to satisfy the concerns of Local Authorities (particularly Highland Council) who feared their powers would be weakened through the creation of a National Park Authority (Illsley and Richardson 2004). Some interviewees perceive the 'call in' system to have worked well:

"The way we work planning is the best way for national parks. Things like porches and extensions shouldn't be decided by the National Park Authority, yet they [CNPA] have the ability to 'call in' the applications of significance that need more scrutiny" (Cairngorm farmer). 
"I would have a problem with powers all going to the [national park] authority because I think it would undermine the spirit of the enabling legislation" (Local business owner).

Others were less convinced and supported the CNPA assuming full planning powers (including now the Local Authorities/Councils):

"I was probably the one pushing for 'call in', I didn't trust the organisation [the CNPA] at the time to have full planning powers. But it is probably seen as quite a complex system. I think there is a kind of muted understanding across all the Authorities that the CNPA should have full planning powers" (a Highland Councillor).

".... planning is such an important aspect of land use management that it should be under the control of the National Park Authority. It's the cutting edge of the National Park Authority, it gives them the ability to fulfil their remit" (Cairngorms conservationist).

Notably, the Northern Ireland White Paper (DoE 2011a: 33) proposes to further downgrade the regulatory functions of a potential NPA: 'a park management body would not exercise any planning powers in its own right. ... New national park legislation would not disturb this [existing planning policies]'.

Northern Ireland Environment Link (NIEL 2011: 4) urged 'the Department to consider the shift of planning powers to the park management authority, with the possible option of a partnership arrangement with local councils'. However, planning powers are intended to remain with local authorities (a Mourne national park authority would not possess 'call in' powers although there is some suggestion that it could become a statutory consultee in the planning process). Therefore, national park designation would not be accompanied by enhanced planning controls. Illsley and Richardson (2004) noted the potential for local authorities (through possession of development control functions) to facilitate the prioritisation of economic development at the expense of the environment within national parks.

While this is further evidence that socio-economic development is to be given priority over conservation, this decision is further complicated, and perhaps influenced, by the wider planning and governance context in Northern Ireland. In the context of the historic democratic void (Wilford and Wilson 2001), the relatively recent return to a devolved Northern Ireland Assembly, the controversial history of rural planning (Murray, 2010), and the transferring of planning powers (planning among other powers were removed from local councils in 1972 amid escalating sectarian conflict) back to local councils (from April 2015 onwards), it would be a controversial move to transfer powers, such as development control functions, to a NPA. Interviewees already questioned the current minimal management arrangements in the Mournes (MHT), due to its "unelected" and "unrepresentative" status. Despite the perceived environmental benefits of an independent NPA, one conservationist even suggested this could be a step too far for Northern Ireland:

"I am always very suspicious, just as the farmers are, that if you bring [in] small management bodies [such as, a national park authority] there will always be a local sentiment saying: 'who are these people?'... there is an issue about local accountability especially in Northern 
Ireland... I think it would be much better if it [planning] was a local authority or management body within the local authority" (Mourne conservationist).

While the possession of 'call in' powers to determine significant planning applications means that the CNPA retains substantial regulatory clout, a complete lack of development control powers could deprive a Mourne national park body of any regulatory function, rendering it impotent in the face of growing economic development and tourism pressures. Environmental interests generally opposed planning powers remaining with the local authorities for the Mourne area. The argument was passionately conveyed by a local politician:

"There has to be a National Park Authority with ... it HAS to have planning. Without planning the whole thing is a waste of time because if you can't control one of the things driving the loss of the resource then why bother?"

\section{Competing National Identities: a contested socio-political legacy}

Since its origins, the national park movement has been characterised by strong nationalist tenets, with Ramutsindela (2004: 29) alleging that national parks 'have featured strongly in state-building processes'. Many of the first national parks designated in America, Canada and Australia were part of an emerging nationhood and became symbolic of post-colonial national identity reconstruction. For example, according to Beinart and Coates (1995) and Dilsaver (1997) the American association of wilderness with national identity represented the pursuit of a cultural identity forged out of natural grandeur to rival the cathedrals and castles of Europe. For others (Ramutsindela 2004: 25), the designation of national parks came to symbolise 'landscapes of imperial power...Native Americans were excluded from the nationalism that had been built upon the very same land they occupied'. Early national parks were underpinned by nationalist sentiment and continue to possess political connotations linked to the construction of nation States and the expression of cultural identity.

In Scotland, the post-devolution political expediency to designate national parks appears to have been influenced by a Scottish nation building agenda: according to Rennie (2006: 228) national parks became a 'flagship statement' linked to the 'post-devolution nationalist fervour'. Whereas in the Scottish context national parks symbolised a sense of national identity, in a deeply divided society such as Northern Ireland (Bell et al. 2010; Dawson 2007; Doherty 2000) a national park agenda has the potential to further 'divide'. The enduring legacy of colonial rule is clearly evident in Ireland in the form of sectarian violence and civil unrest. In this context, Bell and Stockdale (2015b) identified the added political significance of owning land in the Mournes. The national parks policy unfolded around the time of the wider land reform agenda in Scotland which contributed to alleviating fears amongst some landowners concerning a national park. Conversely, landowner opposition to a national park in the Mournes was fuelled by complex and often contested land ownership and access arrangements.

Blighted by 'The Troubles' in its recent past, Northern Ireland possesses a legacy of national identity contestation characterised by entrenched cultural differences and distinct ethnic geographies (British and Irish). The Mournes are situated just North of the British/ Irish border in the south-east corner of Northern Ireland (Figure 2). 
Figure 2 Newry and Mourne Local Government District in relation to the Northern Ireland/Republic of Ireland border

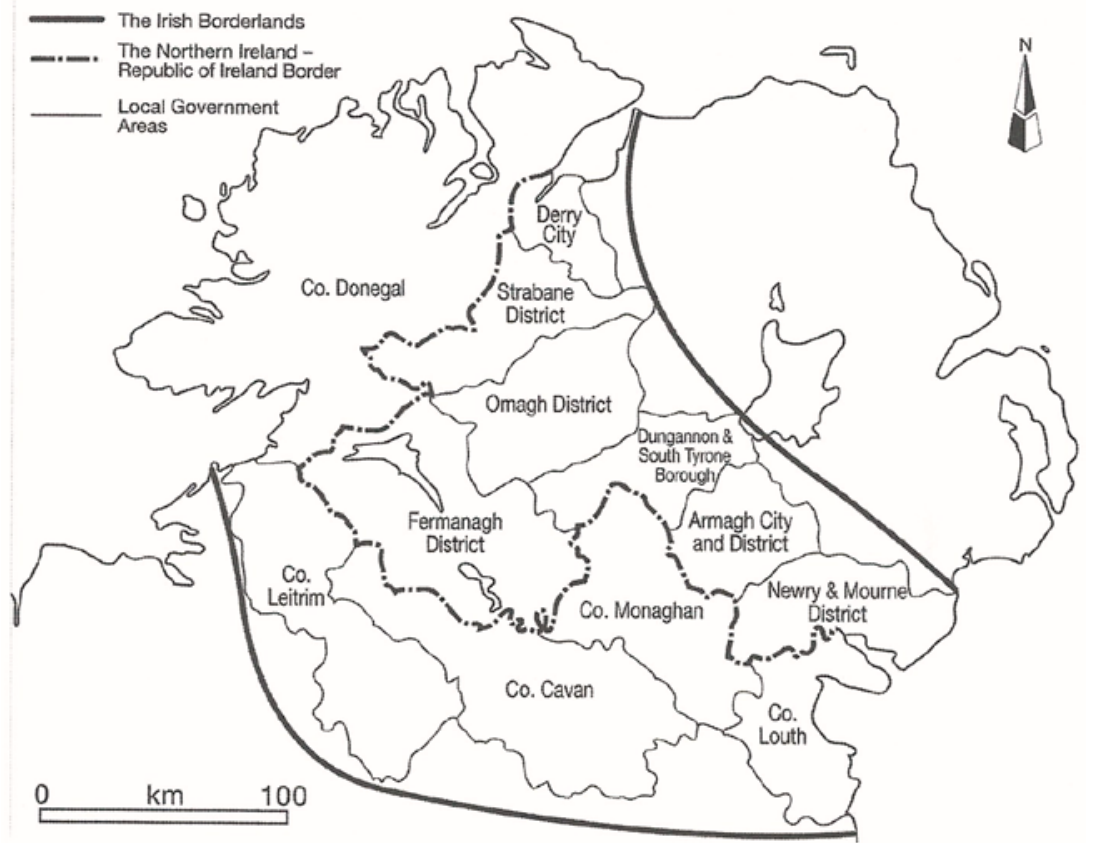

Source: Murray (2010: 48)

According to Bell et al. (2010: 18) the Irish border 'could loosely be conceptualised as the largest 'interface' on the island [of Ireland], and one of the principal drivers behind the political conflict in Ireland both historically and in more recent times ...'. The differing social construct between Protestants and Roman Catholics living within Northern Ireland is summarised by Elliott (2002): 'Protestant determination to cling to the Union with Britain' (p. 174) and describes the '[British] State and its representatives ... [as the] bogeyman' (p. 170) for Roman Catholics. In common with much of Northern Ireland, the Mournes consist of a mosaic of distinctly Roman Catholic/ Nationalist and Protestant/ Unionist coastal and rural communities. Northern Ireland's recent troubled history has affected this highly segregated area:

"the Mournes was a hotbed of sectarian tension during 'The Troubles'" (Mournes resident).

Despite this, local interviewees were keen to convey that the anti-national park campaign was organised along stakeholder lines, rather than sectarian lines:

"I don't think the religious thing entered into it because I know the landowning meetings were totally cross-community ... I haven't witnessed or experienced a sectarian element";

"It was quite amazing, it was a mixture within the 'no camp', they were all in it together, Nationalists and die-hard Unionists".

The contested ethno-national and political identities, however, were never far beneath the surface as many stakeholders unwittingly disclosed at interview. 
First, the Park's proposed boundary raised considerable controversy. Consultants commissioned by the MNPWP to assess possible national park boundary options excluded the mainly Protestant coastal strip arguing:

'... its landscape and recreational opportunity are not considered to be of National Park standard' (Alison Farmer Associates and Julie Martin Associates 2005: 60).

Whatever the justification, any national park boundary that excluded the main Protestant (and Unionist) communities was going to be controversial. This was acknowledged by a local Sinn Fein (Nationalist) politician:

"[We are] concerned that it could appear there has been a sectarian carve up with [the] Nationalist community within the [national park] boundary and Unionist outside it".

Significantly, the Mourne National Park Working Party Report (2007) to government recommended the inclusion of the coastal area (and with it Protestant/ Unionist communities). It is surely no coincidence that this decision averted political controversy and with it any perception that a Mourne national park would benefit one community (Nationalist) over the other (Unionist). Officially, the decision was justified on the basis that:

'[the coastal area] forms an integral part of the Mourne landscape and cultural heritage, linking the sea to the mountains, and presents recreational opportunities to take pressure off more sensitive areas: it would be crucial to the effective management of the area' (MNPWP 2007: 34).

Second, the MNPWP report (2007) acknowledged some support for a cross-border national park: one that included not only the Mournes (in Northern Ireland) but also controversially the Cooley Mountains (in Co Louth in the Republic of Ireland). While this suggestion was not taken forward or debated to any great extent (probably because most if not all, even its supporters, recognised it as a step too far in the context of Northern Ireland politics) the Mournes national park debate still became ensconced in localised concerns over geo-political segregation.

The national park debate generated nationalistic sentiment among some sections of the Nationalist landowning community. They claimed that to support a national park in Mourne, it needed to fulfil their interpretation of 'national': a national park embracing land on both sides of the border. One interviewee alleged that this was perceived by the Unionist community as a threat to the union with Britain:

"[Nationalists] want a national park if it's cross border, because in effect that would do away with the border .... contributing to their cause for Irish unity".

Donnan (2006) suggests that border Protestants understand their identity in relation to the border: the area has a large Nationalist majority comprised of two-thirds Roman Catholic (up from 59 percent in 1991) and among some Unionists the national park agenda was tied up with fears over further Nationalist encroachment: 
"[I detected] a subconscious 'No Surrender' sentiment ... because the people that had lost the power politically in this area (Unionists) said 'this is another thing we're losing'" (former Unionist councillor).

Equally, some within the Nationalist landowning community opposed a national park because, as explained by a local Sinn Fein supporter:

"[Nationalist landowners] ... see it [national park] as being imposed by the British State; they're trying to take our land off us and we fought hard and long and sweated on the lands and now they're looking to put more controls on us".

Indeed, some stakeholders at interview perceived the opposition from extreme elements in the area to be such that certain individuals would do almost anything in their power to disrupt a Mourne national park, including the possible use of violence:

"There was talk ... that all it takes is a little [Troubles-like] incident in Newcastle [the main tourist town in the Mournes] and the government's tourism dream goes down the pan".

"I'm sure if it [national park] wasn't on an all-island basis then they [extreme elements within the Nationalist community] would say 'how can this be a national park if it is only up North: they might see reason to attack it then".

Clearly the Mournes national park debate is tied up with wider issues relating to ethno-national identity. Initial understandings of the national park proposal appear to have contributed to instant resistance and defensiveness within both landowning communities; but while united in their opposition they did so from the perspective of differing ethno-national identities. Amongst Unionists this related to the highly emotive issue of the British-Irish border. Conversely among Nationalists it aroused fears of further State/ British imposition. The prospects for a national park in Mourne are therefore mired by underlying tensions concerning ethno-national identity and what constitutes 'national'.

Furthermore, even if a national park is designated in Mourne there will be ongoing issues. Deciding upon local representation within a statutory national park management structure has the potential to ignite similar sectarian concerns relating to power and control over local decision making. In such a segregated area, the geographical coverage of the national park boundary will influence the proportion of Protestant/Unionist and Roman Catholic/Nationalist interests directly elected as members of the national park board. A board dominated by one community could fuel resentment towards the national park and leave the other community feeling that their interests are being neglected. By the same token, manipulating the board make-up to ensure equal representation could risk politicising an issue which may otherwise not become contentious.

\section{Conclusion}

Models of national park have evolved in contemporary times and increasingly possess a strong socioeconomic development/sustainability remit. Northern Ireland is the last remaining jurisdiction within the UK not to have designated a national park: nevertheless, a national park agenda has been pursued since the turn of this century. The model of national park proposed for the Mournes (Northern Ireland) takes much from the model recently introduced in the Cairngorms (Scotland) but 
in several important respects the Mourne model goes a step further with an even stronger economic imperative. It is therefore 'light years' away from the original wilderness and recreation model. This is demonstrated through the ordering of proposed national park aims (its sustainable economic and social development first aim), the omission of any reference to the Sandford Principle as a means to manage potentially conflicting aims, and the absence of any planning functions for the national park management body. Indeed, the model is intended to deliver the wider national economic goals of Government which views the countryside and highly valued landscapes (such as the Mournes) as commodities to be consumed through tourism and recreational activities. It is difficult to view the proposed Northern Ireland model as anything other than a countryside branding and marketing instrument intended to bring about the commodification of natural landscapes and rural space.

At interview, Kathleen Rettie (national park expert) alleged that:

"I think the last thing we need is to become very materialistic or precious about preserving the national park concept...you have to go with the model that works; forcing existing models is not conducive."

It could be argued that what is proposed for Northern Ireland is Government simply developing a model of national park that will work best in Northern Ireland's interest, for example, to use the national park label as a driver for economic growth. Conservation, as an underlying principle of national park designation, has therefore been relegated in importance behind economic development. Today, the significance of conservation as an aim for national parks is within the context of managing the resource paradox and thereby preserving future tourism and economic potential. While this 'thoroughly modern concept ... [views] Parks [as]... 'exemplars of sustainable development" (Arup for National Parks Wales 2013: 9) the 'light touch' park management approach advocated in DoE (2011a) is likely to render a Mourne national park ineffective. Introducing the national park label alongside a largely powerless management body is likely to result in the rapid degradation of the Mourne landscape. A degraded landscape is neither economically nor environmentally beneficial. By comparison, a model of national park which gives primary consideration to the environment, while at the same time facilitating sustainable socio-economic development of the area's communities (as in the Cairngorms National Park) could contribute to the sustainable growth of natural heritage based tourism in Northern Ireland.

Nevertheless, the Cairngorms National Park model has not been without criticism. The postdesignation experiences of the Cairngorms National Park demonstrate the difficulty of developing a model of national park which satisfies the broad range of stakeholder interests that exist within such multifunctional landscapes. These experiences highlight the management challenge involved in striking an appropriate balance between environmental, recreational and socio-economic considerations. Conservationists were critical of the perceived priority given to economic interests; whereas business interests were supportive. Individuals associated with the Cairngorms National Park Authority (past and present) even reported that the Authority had 'bent over backwards to show that the environment did not hold sway', while others alleged that within Scottish Natural Heritage there was a broad recognition that the model of national park introduced is not a conservation designation. Some landowning interests felt 'conned' because of a perceived lack of benefits since designation. The role and composition of the Authority Board was reported in broadly 
positive terms, however some remained critical of the unique decision to allow planning powers to (largely) remain with local authorities. Stakeholder opinion continues to be divided on this issue but some have altered their position and now firmly believe that the National Park Authority should assume full planning powers.

From the outset, some Mourne stakeholders adopted an anti-national park stance. This stemmed largely from the initial (2006) consultation experiences and the absence (at that time) of information about the model of national park advocated. With the publication of the National Park White Paper (DoE 2011a) some concerns do seem to be addressed. The inclusion of a socio-economic first aim appears to have allayed fears that designation may turn the area into a 'countryside museum' but others remain sceptical of the need for a national park irrespective of its purported aims. Stakeholders continue to be suspicious of the potential role of what they see will be an autonomous and unelected quango (the national park authority) lacking sufficient local representation and planning powers. It is proposed that the park management body will have no planning powers in its own right (indeed national park designation would not result in any additional regulation beyond existing planning policies). While welcomed by landowners (because it signals that there will be no new or further restrictions placed on their activities), others questioned the purpose of a national park without an ability to control developments leading to the loss of the natural resource.

Comparing similar model characteristics implemented in the Cairngorms National Park with those proposed for the Mournes has helped to highlight contrasting stakeholder views. Some stakeholders remain critical of the Cairngorms National Park model. Equally, notwithstanding the availability now of detail as to the form of national park proposed for Mourne there is little sense of a ground-swell of opinion favouring the introduction of a Mourne national park. Stakeholder experience of the 2006 consultation exercise has left a 'bitter taste' and Mourne farmers, in particular, remain sceptical of the need for a national park in the area believing that existing management arrangements and structures are suffice. Nevertheless, the proposed socio-economic development focus of a Mourne national park does seem to have had an impact on the stance taken by some farming interests. It has not necessarily led to widespread pro-national park views but it has perhaps 'softened' the anti-national park sentiment in Mourne (at least among some).

In Northern Ireland, however, a further political dimension may prove impossible to overcome in the foreseeable future. Competing national identities may be sufficient to derail any plans for the introduction of national parks; irrespective of the model of national park proposed. The topic reveals the deep ideological cleavages that persist among landowners at this emotive border interface: on one hand, there is the protection of Northern Ireland's position within the British Union and, on the other hand, the pursuit of an 'All Ireland' political agenda. Linked to these different nationalistic identities is the challenge of garnering cross-community support for a national park authority/ board and ensuring equal and fair representation from both communities, alongside the practical task of identifying an acceptable national park boundary. The composition of the national park board has the potential to become highly contentious. Accommodating disparate stakeholder interests and negotiating opposing national ideologies to develop a common strategic vision will not be straight forward. Furthermore, considerable effort will be required to rebuild trust and good relations, especially with Mourne landowners, and to provide tangible benefits for those who own land within 
a proposed national park. While Northern Ireland has at present put the national park agenda 'on hold', in the absence of any other designation with a global brand label commensurate with that of a national park, national park designation may re-emerge as an option for maximising the economic potential of protected landscapes. However, the prospect of gaining political support and local acceptance to designate a national park, notwithstanding its economic focus and 'light touch' approach to management, seems as remote as ever. Northern Ireland's distinct national identities and associated deep rooted societal divisions represent ongoing obstacles to the introduction of national parks: indeed a strong economic model might not be enough to offset continuing antinational park sentiment. In a Northern Ireland context, any proposed national park designation is likely to be heavily contested not only on environmental and economic grounds but on political and ethno-nationalistic grounds as well.

\section{Acknowledgements}

The authors are grateful to Northern Ireland Department of Employment and Learning (DEL) for funding this project. We are also indebted to the many stakeholders in the Cairngorms and Mournes who participated in interviews. We also thank the Land Use Policy reviewer for their very helpful comments and suggestions on an earlier version of the paper. 


\section{References}

Alison Farmer Associates and Julie Martin Associates (2005) Mourne National Park Boundary Recommendations. Environment and Heritage Service: Belfast.

Arup for National Parks Wales (2013) Valuing Wales' National Parks. National Parks Wales: Cardiff. Bailey, T. (2010) Scotland's environmental laws since devolution - from rhetoric to reality. Scottish Environment Link: Perth.

Barker, A. and Stockdale, A. (2008) Out of the Wilderness? Achieving sustainable development within Scottish national parks. Journal of Environmental Management 88(1): 181-193.

BBC (2013) National Trust defends Giant's Causeway visitor charge. Available at: http://www.bbc.co.uk/news/uk-northern-ireland-19175369 (Accessed: 27th July 2013).

Beinart, W. and Coates, P. (1995) Environment and history: the taming of nature in the USA and South Africa (first edn). Routledge: London.

Bell, J., Jarman, N. and Harvey, B. (2010) Beyond Belfast: Contested Spaces in Urban, Rural and Cross Border Settings. Community Relations Council: Belfast.

Bell, J. and Stockdale, A. (2009) Towards a multi-purpose model for the proposed Mourne National Park. Irish Geography 42(3): 293-321.

Bell, J. and Stockdale, A. (2015a) Comparing the political imperative to designate new national parks in a devolved Scotland and Northern Ireland, in F. Gaffikin, S. McKay, M. Murray, B. Murtagh and K. Sterrett (eds.) A Sense of Place: Multidisciplinary Essays in Honour of Malachy McEldowney, pp.239254, Belfast, ISEP, Queen's University Belfast.

Bell, J. and Stockdale, A. (2015b) Participatory governance and contemporary power dynamics in the contested UK countryside. Journal of Rural Studies (under review).

Bishop, K., Green, M. and Phillips, M. (1998) Models of National Parks. Scottish Natural Heritage: Perth.

Bjorkhaug, H. and Richards, C.A. (2008) Multi-functional agriculture in policy and practice? A comparative analysis of Norway and Australia. Journal of Rural Studies 24(1): 98-111.

BBC News (Northern Ireland) Environment Minister Mark H Durkin shelves national parks plan (11 November 2013).

Brown, K. (2002) Innovations for conservation and development. Geographical Journal 168(1): 6-17.

Buchanan, C and Partners (2006) Tourism in Mourne: Current and Potential Economic Impact. Colin Buchanan and Partners: Belfast. 
Buchanan, R.H. (1982). Landscape. The recreational use of the countryside, in J.G. Cruickshank and D.N. Wilcock (eds.), Northern Ireland. Environment and Natural Resources, The Queen's University of Belfast: Belfast, pp. 265.

CNPA (2010) The Economic and Social Health of the Cairngorms National Park. Cairngorms National Park Authority: Grantown-on-Spey.

Cairngorms Working Party (1993) Common Sense and Sustainability. A Partnership for the Cairngorms. HMSO: Edinburgh.

Cantore, N., Kennan, J. and Page, S. (2011) CAP reform and development. Introduction, reform options and suggestions for further research. Overseas Development Institute (ODI): London.

Cloke, P. (1993) The countryside as commodity: new rural spaces for leisure, in S. Glyptis (ed.) Leisure and the Environment. Belhaven: London.

Coppock, J.T. (1980) Price of Progress. The Geographical Magazine 11(6): 422.

Countryside Access and Activities Network (2007) Mourne Area of Outstanding Natural Beauty Access Study. CAAN: Belfast.

Countryside Commission for Scotland (1990) The Mountain Areas of Scotland: Conservation and Management. Countryside Commission for Scotland: Edinburgh.

Dawson, G. (2007) The Troubles on the Border: Ulster-British Identity and the Cultural Memory of Ethnic Cleansing, in G. Dawson (ed.) Making Peace with the Past (first edn). Manchester University Press: Manchester, pp. 209.

Denzin, N.K. and Lincoln, S.Y. (2000) Introduction: The Discipline and Practice of Qualitative Research in N.K. Denzin and Y.S. Lincoln (eds.) Handbook of Qualitative Research (second edn). SAGE: Thousand Oaks: California, pp. 1-29.

DETI (2010) A Draft Tourism Strategy for Northern Ireland to 2020. Department of Enterprise, Trade and Investment: Belfast.

Department of Environment, Food and Rural Affairs (2010) English national parks and the Broads: UK government vision and Circular 2010. DEFRA: London.

DoE (2000) Northern Ireland Landscape Character Assessment. Corporate Document Services: Leeds.

DoE (2011a) White Paper on Proposed Enabling Legislation for National Parks. Department of the Environment: Belfast. 
DoE (2011b) Consultation document on enabling legislation for national parks. Department of the Environment: Belfast.

Dilsaver, L.M. (1997) America's national park system: the critical documents. Rowman and Littlefield: Lanham.

Dinnie, E., Blackstock, K.L. and Dilley, R. (2012) Landscapes of challenge and change: contested views of the Cairngorms National Park. Landscape Research 37(4): 451-466.

Doherty, P. (2000) The Northern Ireland Peace Process: A Solution to the Problems of an Ethnically Divided Society. The Brown Journal of World Affairs 7(1): 49-62.

Donnon, H. (2006) Fuzzy Frontiers: The Rural Interface in South Armagh. University College Dublin: Dublin.

Dower, M (1999) Experience from national parks elsewhere. In: National Parks for Scotland, Conference Proceedings: Developing proposals for national parks. Scottish Natural Heritage: Perth (Scotland).

Edwards, R. (2010) Are Scotland's national parks failing us? (20th June). Herald and Times Group: Glasgow.

Elliott, M. (2002) Religion and Identity in Northern Ireland. in Elliott (ed.), The Long Road to Peace in Northern Ireland. Liverpool University Press: Liverpool, pp. 169.

Forsyth, B., Downie, A. and Dow, S. (2001) Report 3: The Report on the proposal for a Cairngorms National Park in the Cairngorms. Scottish Natural heritage: Edinburgh.

Frost, W and Hall, M (2009) Tourism and National Parks: International perspectives on development, histories and changes. Routledge: Oxon.

Gimingham, C.H. (2002) Introduction in C.H. Gimingham (ed.) The Ecology, Land Use and Conservation of the Cairngorms. Packard Publishing: Chichester.

Goldsmith, F.B. and Warren, A. (1993) Conservation in Progress. John Wiley and Sons: Sussex.

Hamin, E.M. (2002) Western European Approaches to Landscape Protection: A Review of the Literature. Journal of Planning literature 16(3): 339.

Harroy, J.P., Tassi, F., Pratesi, F. and Humphries, C. (1974) National Park's of the World. Orbis Publishing: London. 
Holdgate, M (1992) Protected areas in the future: the implications of change and the need for new policies. Paper presented at the IVth World Congress on National Parks and Protected Areas. IUCN: Caracas.

Ilbery, B. and Bowler, I. (1998) From Agricultural Productivism to Post-Productivism, in B. Ilbery (ed.), The Geography of Rural Change (first edn). Addison Wesley Longman: London, pp. 57.

Illsley, D. and Richardson, T. (2004) New national parks for Scotland: coalitions in conflict over the allocation of planning powers in the Cairngorms. Journal of Environmental Planning and Management 47(2): 219-242.

International Union for the Conservation of Nature and Natural Resources (1994) Parks for Life: action for protected areas in Europe. IUCN: Gland.

International Union for the Conservation of Nature and Natural Resources (2002) Management Guidelines for IUCN Category V Protected Areas. IUCN: Gland.

International Union for the Conservation of Nature and Natural Resources (2008) Guidelines for Applying Protected Area Management Categories. IUCN: Gland.

Knox, C. (2012) The reform of public administration in Northern Ireland: a squandered opportunity? Administration 60(1): 117-138.

Lambert, R.A. (2001) Contested Mountains: Nature Development and Environment in the Cairngorms Region of Scotland, 1880-1980. White Horse Press: Cambridge.

Lake District National Park Authority (2011) Notice of Refusal of Consent to Application - Application Reference Number: 7/2011/2054. Lake District National Park: Kendal.

Locke, H. and Dearden, P. (2005) Rethinking Protected Area Categories and the New Paradigm. Environmental Conservation 32(1): 1-10.

Mackay, J. (2005) People, recreation and the mountains with reference to the Scottish highlands, in D.B.A. Thompson (ed.), Mountains of Northern Europe: Conservation, Management, People and Nature. TSO Scotland: Edinburgh, pp. 127-136.

Magee, K. (2013) Giant's Causeway parking rip off say politicians, Available at: http://www.bbc.co.uk/news/uk-northern-ireland-22773323 (Accessed: 12th July 2013).

Marsden, T. (1999) Rural futures: the consumption countryside and its regulation. Sociologia Ruralis 39(4): 501-20.

Marsden, T. and Sonnino, R. (2008) Rural development and the regional state: Denying multifunctional agriculture in the UK. Journal of Rural Studies 24(4): 422-431. 
Mason, J. (2002) Qualitative Researching (second edn). Sage: London.

Mayer, M.; Muller, M.; Woltering, M.; Arnegger, J. and Job, H. (2010) The economic impact of tourism in six German national parks. Landscape and Urban Planning 97(2): 73-82.

McAreavey, R. and McDonagh, J. (2010) Sustainable Rural Tourism: lessons for rural development. Sociologia Ruralis 51(2): 175-194.

McCarthy, J, Lloyd, M.G. and Illsley, B. (2002) National Parks in Scotland; Balancing Environment and Economy. European Planning Studies 10(5): 665-670.

McCool, S. (2009) Constructing partnerships for protected area tourism planning in an era of change and messiness. Journal of Sustainable Tourism 17(2): 133-148.

Mourne Heritage Trust (2007) An Introduction to the Mourne Biodiversity Action Plan - A reflection of Mourne's Rich Natural Heritage. Mourne Heritage Trust: Newcastle (NI).

Mitchell, A. (1999) The evolution of environmental management in Mourne, in Policies and Priorities for Ireland's Landscapes (ed. The Heritage Council). The Heritage Council: Co. Offaly, pp. 103-117.

Mitchell, C.J.A. (1998) Entrepreneurialism, Commodification and Creative Destruction: a Model of Post-modern Community Development. Journal of Rural Studies 14(3): 273-286.

Mitchell, C.J.A. and de Waal, S.B. (2009) Revisiting the Model of Creative Destruction: a model of post-modern community development: St. Jacob's, Ontario, a decade later. Journal of Rural Studies 25(1): 156-167.

Mourne Area of Outstanding Natural Beauty Residents Action Group (2011) Response by the Mourne Area of Outstanding Natural Beauty Residents' Action Group to the White Paper on Proposed Enabling Legislation for National Parks. MAONBRAG: Kilkeel.

Mourne National Park Working Party (2007) Report to the Minister. Environment and Heritage Service: Belfast.

Mourne Trustees (2010) Report on the outcome of the Mourne national park consultation exercise by nominees of the Mourne Trustees. Newcastle (NI).

Murray, M. (2010) Participatory Rural Planning: Exploring Evidence from Ireland (first edn). Ashgate: Farnham.

Northern Ireland Executive (2008) Programme for Government 2008-2011. Northern Ireland Executive: Economic and Policy Unit. 
Northern Ireland Executive (2011) Northern Ireland Executive Economic Strategy: Consultation on priorities for sustainable growth and prosperity. Northern Ireland Executive: Belfast.

Northern Ireland Executive (2012) Programme for Government 2011-15. Northern Ireland Executive: Belfast.

Northern Ireland Environment Link (2011) Comments on Consultation Document on Enabling Legislation for National Parks. Northern Ireland Environment Link: Belfast.

Northern Ireland Environmental Policy Group (2004) National Parks and other Protected Landscape Areas: A discussion of options for establishing national parks and managing other outstanding landscapes in Northern Ireland. Department of the Environment: Belfast.

Northern Ireland Planning Advisory Board (1947) The Ulster Countryside Report. Northern Ireland Planning Advisory Board: Belfast.

Oliveira, J.A.P. (2003) Governmental responses to tourism development: three Brazilian case studies. Tourism Management 24(1): 97-110.

Plog, S.C. (1974) Why destination areas rise and fall in popularity. Cornell Hotel and Restaurant Administration Quarterly 14(4): 55-58.

Ramutsindela, M. (2004) Parks and People in Postcolonial Societies. Experiences in Southern Africa (first edn). Kluwer Academic Publishers: London.

Rennie, A. (2006) The importance of National Parks to nation building: support for the National Parks Act (2000) in the Scottish Parliament. Scottish Geographical Journal 122(3): 223.

Rettie, K.M. (2001) The Report on the proposal for a National Park in the Cairngorms. An independent assessment of the consultation on the proposed National Park for the Cairngorms. SNH: Edinburgh.

Schumpeter, J.A. [1934](2008) The Theory of Economic Development: An Inquiry into Profits, Capital, Credit, Interest and the Business Cycle. Translated from the German by Redvers Opie, New Brunswick (U.S.A) and London (U.K.): Transaction Publishers.

Scott, K. (2011) Loch Lomond goldmine approval sparks fears for national park, Available at: http://www.guardian.co.uk/environment/2011/oct/30/loch-lomond-goldmine-national-park (Accessed: 8th December 2011).

Scottish Natural Heritage (1999) National Parks for Scotland - Scottish Natural Heritage's advice to government. SNH: Perth.

Shortall, S. and Shucksmith, M. (2001) Rural Development in Practice: issues arising in Scotland and Northern Ireland. Community Development Journal 36(2): 122-133. 
Shucksmith, M. (2012) Future Directions in Rural Development. Carnegie UK Trust: Dunfermline.

Stewart, L. (2013) Fears for Giant's Causeway World Heritage status, Available at: http://www.belfasttelegraph.co.uk/news/local-national/northern-ireland/fears-for-giantcauseways-world-heritage-status-29102400.html (Accessed: 27th July 2013).

Stockdale, A. and Barker, A. (2009) Sustainability and the multifunctional landscape: An assessment of approaches to planning and management in the Cairngorms National Park. Land Use Policy 26(2): 479-492.

The Scottish Parliament (2000) National Parks (Scotland) Act. The Stationary Office Limited: Edinburgh.

UK Association of National Park Authorities (2013) The impacts of tourism, Available at: http://www.nationalparks.gov.uk/learningabout/ourchallenges/tourism/impactsoftourism.htm (Accessed: 15th April 2013).

Valentine, G. (2005) Tell me about....using interviews as a research methodology, in R. Flowerdew and D. Martin (eds.) Methods in Human Geography (second edn). Pearson Education Limited: Harlow, pp. 110.

Warren, C. (2002) Of superquarries and mountain railways: recurring themes in Scottish environmental conflict. Scottish Geographical Journal 118(2): 101-127.

Warren, C. (2009) Managing Scotland's Environment (second edn). Edinburgh University Press: Edinburgh.

Watson, A. (1980) Conflict in the Cairngorms: Policies for Protection. The Geographical Magazine 52(6): 427-445.

Watson, A. (2003) An expensive farce. A letter published in The Scotsman (8 September 2003). Johnson Press Digital Publishing: Edinburgh.

Watson, A. (2005) The Cairngorms National Farce. The Angry Corrie (64): TACit Press: Stirling.

Wilford, R. and Wilson, R. (2001) A Democratic Design? The Political Style of the Northern Ireland Assembly, UCL Constitution Unit: London.

Williams, P.W. and Ponsford, I.F. (2009) Confronting tourism's environmental paradox: Transitioning for sustainable tourism. Futures 41(6): 396-404.

Woods, M. (2007) Engaging the Global Countryside: globalisation, hybridity and the reconstitution of rural place. Progress in Human Geography 31(4): 485-507. 
Woods, M. (2011a) Rural (first edn). Routledge: London.

Woods, M. (2011b) The local politics of the global countryside: boosterism, aspirational ruralism and the contested reconstitution of Queenstown, New Zealand. GeoJournal 76(4): 365-381.

World Commission on Environment and Development (1987) Our Common Future. Oxford University Press: Oxford.

Yin, R.K. (2003) Case study research: Design and methods (third edn). Sage: Thousand Oaks. 